\title{
Management of a Traumatic Wound in a Malnourished Orphan Asian Baby Elephant (Elephas maximus)
}

\author{
Das BC ${ }^{1 *}$, Ahaduzzaman $\mathrm{M}^{1}$, Akter $\mathrm{S}^{1}$, Hossain $\mathrm{F}^{2}$, Faruque $\mathrm{MR}^{1}$, Sutradhar BC ${ }^{1}$ \\ ${ }^{1}$ Department of Medicine and Surgery, Chittagong Veterinary and Animal Sciences University, Zakir Hossain \\ Road, Khulshi, Chittagong- 4225, Bangladesh; ${ }^{2}$ Artificial Insemination Center, Chittagong, Bangladesh
}

[Received: March 2, 2015; Accepted: May 11, 2015]

\begin{abstract}
The present case report was carried out to evaluate the outcome of traumatic wound in a malnourished orphan elephant calf. A 1.5 month old, female Asian Elephant calf approximate weighing $100 \mathrm{~kg}$, was admitted to the Teaching Veterinary Hospital, Chittagong Veterinary and Animal Sciences University, Bangladesh, with a history of squeezed and trapped in natural tree during foraging, detached from the herd, rescued by nearest forest people and treated by local veterinarian. The baby elephant was dull, depressed, dehydrated and emaciated on clinical examination. A local swelling $(65 \mathrm{~cm})$ was noticed on left hind limb(stifle joint) and a circular wound on lateral aspect of the limb where mild discharge was noticed. Gait and posture was not normal. Wound swab, blood and fecal sample were collected and sent to the respective departments. Pyogenic organisms were found in wound swab culture. Blood parameters revealed lower value of TEC, Hg, PCV, glucose and total protein. No parasite or ova were found in fecal sample. The elephant calf was fed with powder milk as $10 \%$ of total body weight (10 liters/day at 1 hour interval). Ceftriaxone sodium @ $20 \mathrm{mg} / \mathrm{kg}$ bwt along with pain killer ketoprofen @ $3 \mathrm{mg} / \mathrm{kg}$ bwt, amino acid solution@20 ml hematinic preparation@10 ml, vitamin ADE preparation@10 ml along with 5\% dextrose saline (2liters/day), local application of Dressgel ointment (herbal preparation) and wound dressing with povidone iodine at regular interval as required until healing. The calf revealed improved condition such as more active and alert, improved gait, reduced local swelling and no discharge from the wound. The $\mathrm{CBC}$ and serum biochemical parameter was also improved by day 4 while the calf was shifted to Dulahazra safari park, Chokoria, Chittagong.
\end{abstract}

Keyword: Asian Elephant, Wound, Malnutrition, Management, Antibiotic

\section{INTRODUCTION}

Asian elephants (Elephas maximus) are the giant herbivores mammals. The Asian elephants were historically distributed through Asian continent. Unfortunately, Asian elephant populations are now only distributed in some isolated scattered pocket of tropical forest and grassland in 13 Asian countries. Illegal Killing (poaching), loss of habitat, elephant human conflict due to increased pressure of human growth and calf mortality are the major challenges for elephant conservation ${ }^{[1]}$.International Trade in Endangered Species of Wild Flora and Fauna (CITES) classified Asian elephant as an endangered or threatened species [2]. In many constant they suffer from man-made or natural catastrophe such as loss of habitat, attacked by human or other mates, social looser and become orphan. However, injury and infection in the skin and soft tissue of natural elephant population is one of the frequent case encountered by wildlife veterinarian ${ }^{[3]}$. The severity of a wound is largely depends on its anatomical position and function to carry out. The foot of elephant is a highly evolved appendage that not only supports the enormous weight of the largest terrestrial mammal but also can withstand enormous concussion ${ }^{[4]}$.Moreover, optimal wound healing not only relies on the medical therapy but also the nutritional status of the patient. Malnutrition interfere the normal processes that allow advancement through stages of wound healing. Malnutrition has also been linked to decreased wound tensile strength and increased secondary infection rates ${ }^{[5]}$. This condition becomes more enigmatical in orphan elephant calf due to unavailability of large quantity of dam milk to nourish it artificially.

Over the past two decades the world has seen tremendous advances in modern medical wound care management, principally due to development of new scientific knowledge, skill, techniques, materials and facilities ${ }^{[6]}$. These advances have occurred mainly in developed countries and concentrated to public health but bit improvement towards animal health and full picture of their outcome is still obscure. The wound treatment and outcome of wild elephant is not also well documented in the world. Therefore, the case report is presenting the management and treatment outcome of traumatic wound in a malnourished orphan Asian baby elephant.

\section{Case Description}

A 1.5 month old, $100 \mathrm{~kg}$ body weight, female Asian Elephant (Elephas maximus) calf was admitted to the S.A Quadery Teaching Veterinary Hospital, Chittagong Veterinary and Animal Sciences University, Bangladesh at 28, September 2014 with a history of squeezed and trapped in a natural tree during foraging and detached from the herd (became orphan) which is rescued by nearest forest people and treated by local veterinarian. The rectal temperature was recorded as 101, 99.5, 99 and 99.5 ${ }^{0} \mathrm{~F}$ while the heart rate was $59,58,60$ and 58 
beat/minute (bpm) in 4 subsequent day of treatment accordingly.

A circular traumatized wound was noticed in the lateral aspect of stifle joint ( Fig. 1) which was characterized by $65 \mathrm{~cm}$ diameter in the first day( Fig.2). The wound diameter gradually reduced towards normal in therapeutic management as 65, 63, 62 and $60 \mathrm{~cm}$ in subsequent follow-up day. Pyogenic infection manifested by pus and oozing of serous fluid was seen from wound area in admitted date but no such condition was found in released date. Foul smell from the wound, mild corneal opacity and rough body coat were found on the first day. Fecal sample was collected directly from the rectum for coproscopy. Direct smear, sedimentation and floatation techniques were adopted to perform coproscopy but no parasite or ova were found. The right stifle was found in normal condition and considered as control to compare the clinical improvement of wound noticed in left. Treatment protocol used for the management of traumatized wound in malnourished Asian elephant calf was described in table-1 and an indication of anemia. Hemoglobin ( $\mathrm{Hgb})$ was $7 \mathrm{gm} \%$ and $8 \mathrm{gm} \%$ and Packed Cell Volume (PCV) was $23 \%$ and $35 \%$ respectively in day 1 and day 4 that were also under the normal parameter but turned close to the normal at released date which denotes the recovery from anemia. The Erythrocytes Sedimentation Rate (ESR) values were $62 \mathrm{~mm}$ and $60.5 \mathrm{~mm}$ respectively that was closed to the normal reference value. The Total Leucocytes Count (TLC) was 7.65 and 4.9 per cubic millimeter respectively in two tested day and occupied within normal physiological range. The lymphocytes, neutrophils, eosinophils, monocytes and basophils were $66 \%$, $26 \%, 3 \%, 5 \%$ and $0 \%$ respectively in the first day and $70 \%, 24 \%, 2 \%, 4 \%$ and $0 \%$ respectively in the released day. Higher lymphocyte count may be due to infection (Table: 2).

Initial evaluation of serum found lower glucose level $(68.4 \mathrm{mg} / \mathrm{dl})$ but after four days therapy with $5 \%$ dextrose it's become within the physiological range $(92 \mathrm{mg} / \mathrm{dl})$. The hematology of mineral constituents such as calcium, magnesium, phosphorus was 11.2, 4.4 and 3.6 milligram per deciliter respectively in the

Table 1: Treatment protocol used for the management of wound in malnourished Asian elephant calf:

\begin{tabular}{|c|c|c|}
\hline Day & Treatment & Route \\
\hline \multicolumn{3}{|c|}{ Before admitted to SAQTVH (at forest office) } \\
\hline $01^{\mathrm{a}}$ & $\begin{array}{c}\text { Penicillin (Combipen vet }{ }^{\circledR}, \text { Acme pharma. Ltd.) @ } 32000 \text { IU/kg body weight } \\
\text { (BW) }\end{array}$ & $\begin{array}{l}\text { Intra muscular } \\
(\mathrm{i} / \mathrm{m})\end{array}$ \\
\hline $02^{\mathrm{a}}$ & $\begin{array}{c}\text { Ketoprofen }\left(\text { Kop vet }{ }^{\circledR}, \text { Square pharma. Ltd.) @ } 3 \mathrm{mg} / \mathrm{kg} \mathrm{BW}\right. \\
\text { Streptomycin + Penicillin }\left(\mathrm{SP}_{\mathrm{vet}}{ }^{\circledR}\right) @ 2.5 \mathrm{gm}(\mathrm{Combined} \text { total dose }) \\
\text { Pheneramine maleate }\left(\text { Asta vet }^{\circledR}\right) @ 1.5 \mathrm{mg} / \mathrm{kg} \mathrm{BW} \\
\text { Ketoprofen }\left(\text { Kop vet }^{\circledR}\right) @ 3 \mathrm{mg} / \mathrm{kg} \mathrm{BW}\end{array}$ & (18) \\
\hline
\end{tabular}

Gentian violet + Povidone iodine solution $(1 \%)$

Topical in wound

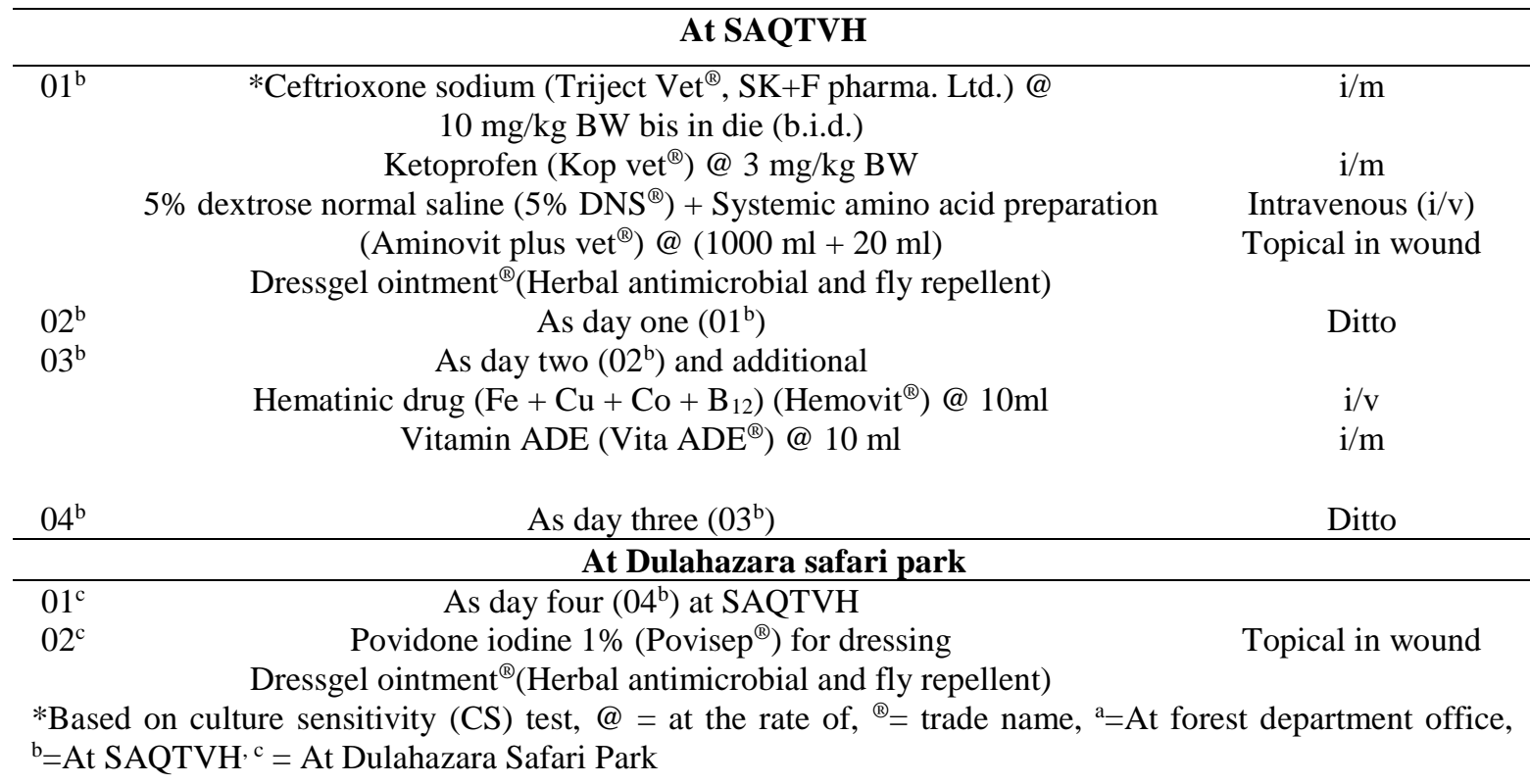

The Total Erythrocytes Count (TEC) was 1.3 and 2.13 million/cu.mm. respectively in date of admitted and released that was below than the normal value first day and stood 11.7, 1.8, 3.5 milligram per deciliter respectively in the fourth day. Exclude calcium the serum magnesium and phosphorus level 
turned down which may be due to dilution of mineral constituents after fluid therapy. Total protein was lowered in both tested days but condition improved from first day $(64 \mathrm{mg} / \mathrm{dl})$ to fourth day $(69 \mathrm{mg} / \mathrm{dl})$ in was higher $(7.30 \%)$ than the normal reference value and thus may be the cause of rapid improvement of serum glucose level in addition of $5 \%$ dextrose saline.

Table 2: Hematological parameters of injured elephant calf Parameter

Tested value

\begin{tabular}{ccc} 
Day 1 & Day 4 & $\begin{array}{c}\text { Reference } \\
\text { value* }\end{array}$ \\
\cline { 1 - 2 } 1.3 & 2.13 & \\
7.65 & 4.9 & 2.42 \\
7.0 & 8.0 & $4.0-11.5^{\mathrm{a}}$ \\
23 & 35 & 11.12 \\
62 & 60.5 & 37.7 \\
66 & 70 & 61.3 \\
26 & 24 & 59.0 \\
3 & 2 & 32.12 \\
5 & 4 & 3.80 \\
0 & 0 & 4.5 \\
& & 0.6 \\
\hline
\end{tabular}

TEC (million/cu.mm.)

TLC (thousands/cu.mm.)

Hemoglobin (Hgb.) (gm \%) PCV $(\%)$

$\operatorname{ESR}\left(\mathrm{mm}\right.$ in $1^{\text {st }}$ hour$)$

Lymphocyte (\%)

Neutrophils (\%)

Eosinophils (\%)

Monocytes (\%)

Basophils (\%)

\section{DISCUSSION}

compare to the reference value (82.50) may be due to systemic amino acid administration. ALT (Alanine Aminotransferase) and AST (Aspartate Aminotransferase) value found 10.90 (U/L), 3.5 $(\mathrm{U} / \mathrm{L})$ and $70.80(\mathrm{U} / \mathrm{L}), 61.20$ respectively in the two separate tested day. Triglyceride value found 125.2 $\mathrm{mg} / \mathrm{dl}$ that was higher than the normal physiological range. Albumin and uric acid was only tested in released date and found $12.3 \mathrm{mg} / \mathrm{dl}$ and $25.7 \mathrm{mg} / \mathrm{dl}$ respectively. Albumin value was lower than the normal value which may be due to malnutrition as a sequel of orphan (Table: 3 ).
The elephant calf shows a higher temperature of $101^{\circ}$ $\mathrm{F}$ than the normal range of $95.5^{\circ} \mathrm{F}$ on presenting day at Teaching Veterinary Hospital [9]. The increased temperature is due to presence of infection in the local wound ${ }^{[10]}$. The recorded heart rate was also higher 59 than the normal ranges (25-30 beats/min). It is possibly due to a new clinical environment and pain in the wound area ${ }^{[11]}$. Oozing from the wound area with foul odour often indicate the secondary bacterial infection by pyogenic bacteria like Staphylococcus sp, Streptococcus $s p^{[12]}$. Present

Table 3: Hemato-biochemical (serum) parameters of injured elephant calf

\begin{tabular}{cccc}
\hline Parameter & \multicolumn{2}{c}{ Tested value } & $\begin{array}{c}\text { Reference } \\
\text { value* }\end{array}$ \\
\cline { 2 - 4 } & Day 1 & Day 4 & $89 \pm 20^{\mathrm{a}}$ \\
Glucose (mg/dl) & 68.4 & 92 & 12.20 \\
Calcium (mg/dl) & 11.2 & 11.7 & 5.54 \\
Phosphorus (mg/dl) & 3.6 & 3.5 & 2.41 \\
Magnesium (mg/dl) & 4.4 & 1.8 & 82.50 \\
Total protein (mg/dl) & 64 & 69 & 10.2 \\
AST (SGOT) (U/L) & 70.8 & 61.2 & 5.6 \\
ALT (SGPT) (U/L) & 10.9 & 3.5 & \\
\hline mg/dl $=$ milligram per deciliter, ${ }^{*}={ }^{[7]},{ }^{a}={ }^{[8]}$, Day $1=$ Admission of the patient, Day 4= Release of the \\
patient
\end{tabular}

Elephant milk was unavailable for the calf during treatment period thus reconstituted powder milk (Lactogen- $2^{\mathrm{R}}$ ) was offered @ 10 liters per day (10\% of the body weight) which was served at one hour interval (1litre/hour). The specific gravity (1.030), total solids $(16.50 \%)$, total ash $(0.70 \%)$, and calcium (86.17 $\mathrm{mg} \%$ ) values of supplied milk was within the normal range of elephant milk. Total protein (2.24) and fat (3.0) percentage was lower than the normal value that may be the cause of muscle breakdown and increase serum AST (SGOT). The milk sugar lactose percentage of the reconstituted supplied milk cases of wound having characteristic pus and odour indicate the pyogenic infection. At the first instance, the local veterinarian administered Penicillin, Streptomycin + Penicillin, Pheneramine maleate, Gentian violet + Povidone iodine solution (1\%) but these drugs are ineffective against this infection. Bacterial culture sensitivity test often recommended choosing an effective antibiotic against the secondary bacterial infection ${ }^{[13]}$. Thus, CS test was performed \& ceftrioxone was administered as per manufacturer guideline. Ceftriaxone is a $3^{\text {rd }}$ generation cephalosporin effective in both Gram's positive \& 


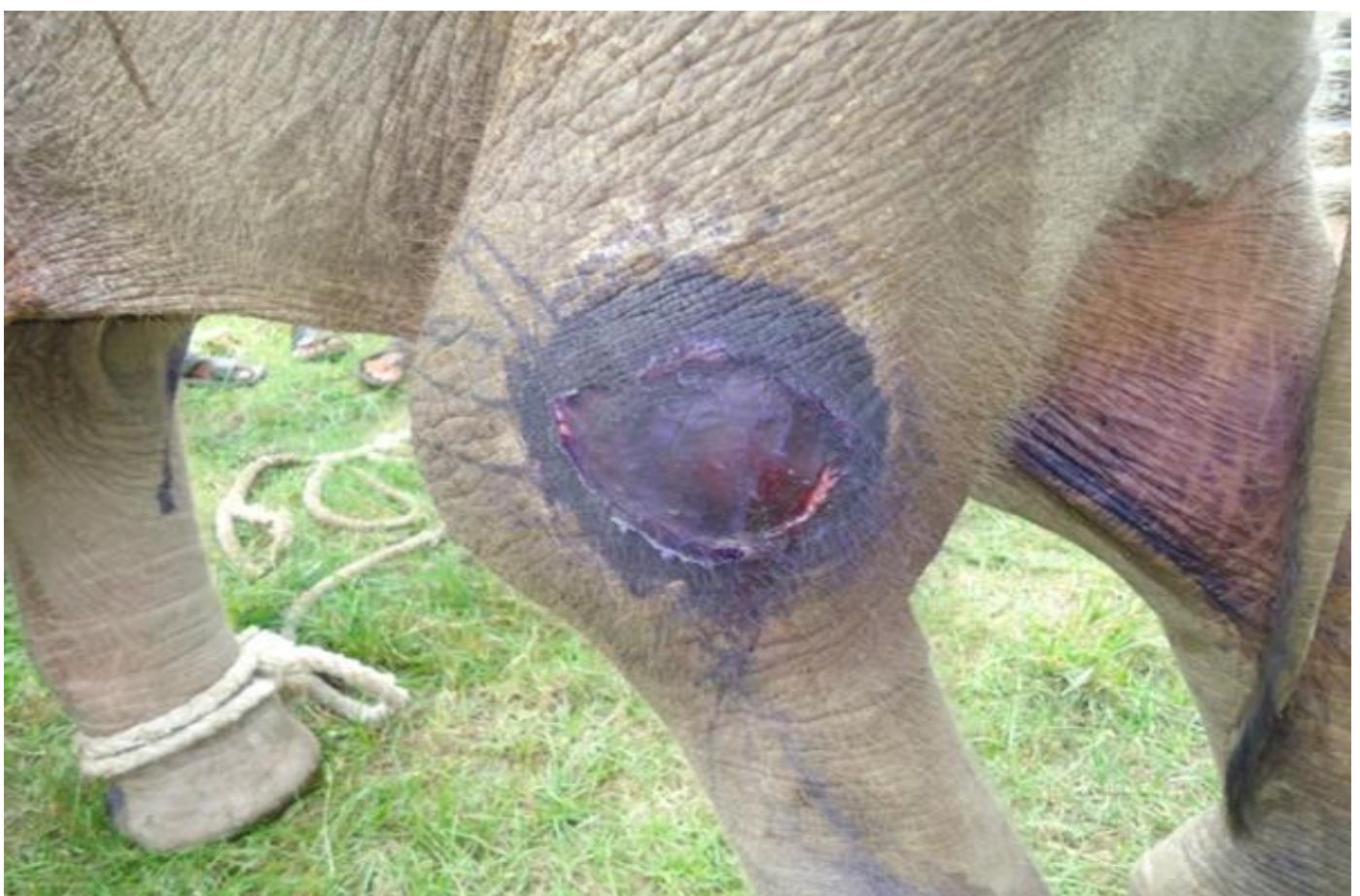

Figure 1: Traumatized wound in the caudo-lateral aspects of left stifle joint

Gram's negative bacteria. Cephalosporin is frequently used for management of wound especially in case of pyogenic infection ${ }^{[14]}$. Ketoprofen was used to subside the pain and inflammation with the antibiotic ${ }^{[15]}$. therapy was administered to the elephant. The lymphocyte count was higher $66 \%$ than the normal range $59 \%$ possibly for the infection in the wound.

In serum evaluation, Blood glucose level and Total protein (TP) found below than the normal range. The

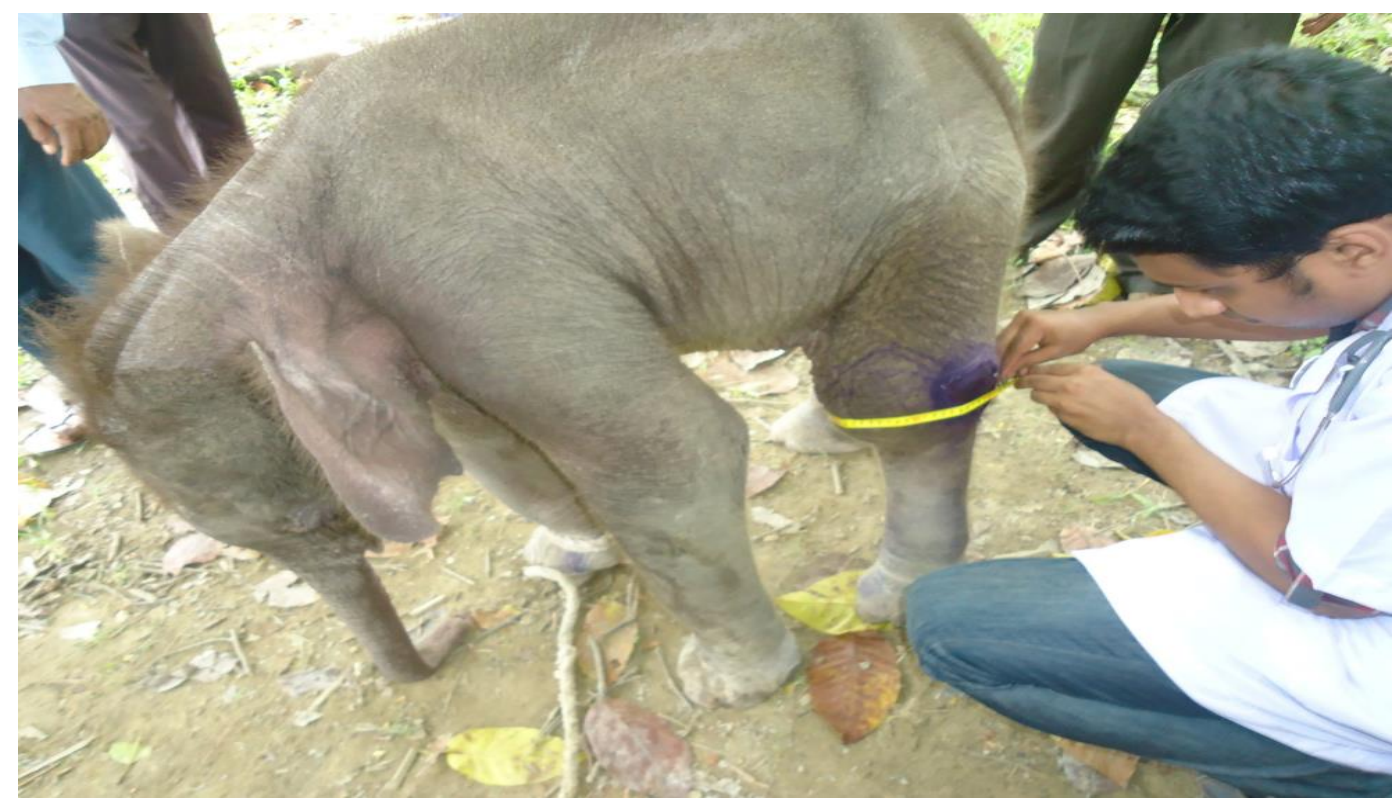

Figure 2: Measuring the diameter of swelling and wound area $(65 \mathrm{~cm}$ diameter $)$ at first day.

The routine hematological examination was performed as it is used to investigate the physiological and nutritional status of an individual [16]. A lower erythrocyte count $1.3 \mathrm{million} / \mathrm{cu} . \mathrm{mm}$ and Hemoglobin $7.0 \%$ was recorded which indicate the anemia and malnutrition in the elephant. Hematinic mixture, vitamin-mineral preparations and fluid therapy (DNS) is often recommended to recover the anemic condition. So the supportive orphan state and malnutrition might be responsible for the lower value. However, the parameter was recovered near to the normal range after administration of DNS and other supportive therapy. Nutritional supplement play a crucial role in rapid healing of wound ${ }^{[17]}$. So the supplementary milk was provided to the elephant according to guidelines. Safari park provide moderate natural environment to the wild animal and effective for rapid healing ${ }^{[18]}$. 
Thus the animal was relocated from clinical setup of TVH to nearest safari park.

\section{ACKNOWLEDGEMENT}

Author would like to thank the authority and personnel of Department of Forestry for refereeing the patient and coordinating during monitoring of the patients.

\section{REFERENCES}

1. Mumby HS, Courtiol A, Mar KU, Lummaa V (2013). Birth seasonality and calf mortality in a large population of Asian elephants. Ecology and Evolution, 3(11): 3794-3803.

2. Gittipongsiri P, Makpun S, Phansod T, Gronsang D, Boonyarittichaikij R, Wiriyarat W (2008). Quality and quantity of Asian elephant (Elephas maximus) peripheral blood mononuclear cells isolated by polymer of sucrose orcolloidal silica solution gradient centrifugation. J. Appl. Anim. Sci, 1 (1):31-38.

3. Dryden MS (2010). Complicated skin and soft tissue infection. J. Antimicrob. Chemother. 65 (3): 35-44

4. Sarma KK, Thomas S, Gogoi D, Sarma M, Sarma DK (2012). Foot diseases in captive elephant.Intas Polivet. 13 (2): 221-227

5. Stechmiller JK (2010). Understanding the Role of Nutrition and Wound Healing. Nutr. Clin. Pract.25(1):61-68.

6. Macdonald J (2010). World Alliance for Wound and Lymphedema Care. Wounds (WAWLC). 22(3):55-59.

7. Ajitkumar G, Anil KS, Alex PC (2009). Health care management of captive Asian elephants. Kerala Agricultural University Press Mannuthy - 680651, Thrissur.

8. Silva ID, Kuruwita VY (1993). Hematology, plasma, and serum biochemistry values in domesticated elephants (Elephas maximus ceylonicus) in Sri Lanka. J Zoo Wildl Med24:440-444.

9. Mikota SK (2008). Appendix 5: Elephant Vital Signs and Physiological Parameters.Biology, Medicine, and Surgery of Elephants, John Wiley \& Sons 499-500.

10. Schwammer HM. (2008). Elephant husbandry and foot care at the
Schonbrunner Tiergarten, Vienna. The Elephant's Foot: Prevention and Care of Foot Conditions in Captive Asian and African Elephants 69-71.

11. Greenberg, Roy K, Haddad F, Svensson L, Neill S, Walker E, Lyden SP, Clair D, and Lytle B (2005). Hybrid approaches to thoracic aortic aneurysms the role of endovascular elephant trunk completion.Circulation 112(17): 26192626.

12. Brook I (2002). Secondary bacterial infections complicating skin lesions.J. med. microbiol. 51(10): 808-812.

13. Bowler PG, Duerden BI, Armstrong DG (2001). Wound microbiology and associated approaches to wound management. Clin. Microbiol. Rev. 14(2): 244-269.

14. Jahan I, Siddiqui O, Ahmed SU, Joarder AI, Faruque S, Imdad S, Sardar K (2014). Wound infection in surgery department in BSMMU: A study of 100 cases. J. Bang. Soci. Anaesth.24(2): 65-69.

15. Duffield TF, Heinrich A, Millman ST, DeHaan A, James S, Lissemore K (2010). Reduction in pain response by combined use of local lidocaine anesthesia and systemic ketoprofen in dairy calves dehorned by heat cauterizationCan. J. Vet. Res. 51(3):283

16. Khan SA, Alauddin M, Hassan MM, Islam SKMA, Hossain MB, Shaikat AH, Islam MN, Debnath NC, Hoque MA (2013). Comparative performance and hematobiochemical profile of Jinding ducks in different production systems of Bangladesh. Pak. Vet. J., 33(1): 113-116

17. Sukklad S, Sommanustweechai A, Pattanarangsan (2006). A retrospective study of elephant wound, wound management from Thai veterinarians. Proceedings of AZWMP. October 26-29, Bangkok, Thailand; 16-17.

18. Mason GJ, \& Veasey JS (2010). How should the psychological well-being of zoo elephants be objectively investigated Zoo. biol. 29(2):237-255. 